\title{
Personalized nanomedicine: future medicine for cancer treatment
}

\author{
This article was published in the following Dove Press journal: \\ International Journal of Nanomedicine \\ 8 January 2013 \\ Number of times this article has been viewed
}

\section{Farooq A Shiekh \\ Avalon University School of Medicine, Willemstad, Curacao}

Correspondence: Farooq A Shiekh Avalon University School of Medicine, Scharlooweg 25, Willemstad, Curacao Email shiekh.fa@gmail.com
Cancer as a grave disease is becoming a larger health problem, ${ }^{1}$ and the medicines used as treatments have clear limitations. ${ }^{2-4}$ Chemotherapy, radiation, and surgery, all of which are drastic treatments, wreak havoc on healthy cells and tissues as well as cancerous ones. ${ }^{5-7}$ Pathophysiologically, there are more than 200 types of cancers, ${ }^{8,9}$ each with many variants. ${ }^{10}$ Some are aggressive, some are not; some are easily treated, and others are always fatal. ${ }^{11}$

Unlike previous "revolutions" in the "war" on cancer that raised hope, nanomedicine is not just one more tool, it is an entire field, and the science in this area is burgeoning, and benefiting from use of modern cutting edge molecular tools. ${ }^{12-14}$ These breakthrough advancements have radically changed the perception of future medicine. Importantly, they are enabling landmark research to combine all advances, creating nanosized particles that contain drugs targeting cell surface receptors and other potent molecules designed to kill cancerous cells. ${ }^{15-19}$ If there is a case to be made for personalized medicine, cancer is it. For example, the current literature reveals the need for a great scientific effort to be made in this field. ${ }^{20-22}$ However, new paradigms are needed to interpret toxicogenomic and nanotoxicological data in order to predict drug toxicities and gain a more indepth understanding of the mechanisms of toxicity, so that more specific therapeutic targets which are essentially devoid of side effects could be selected..$^{23,24}$

The future of nanomedicine and the opportunity to eliminate the suffering and death due to cancer will hinge on our ability to confront cancer at its molecular level. ${ }^{25}$ Nevertheless, there are many outstanding questions that remain unanswered. A revolution in nanoscience is now heralding a long-awaited era of personalized cancer treatment that is now much closer than ever before. Personalized medicine will ensure that such drugs are given only to patients who stand to benefit from them. If that happens, nanobased drugs will be at least less toxic than today's armamentarium for cancer. If they work as intended, they should also prove to be far more effective.

\section{Disclosure}

The author reports no conflicts of interest in this work.

\section{References}

1. Parkin DM. International variation. Oncogene. 2004;23:6329-6340.

2. Sugahara KN, Teesalu T, Karmali PP, et al. Coadministration of a tumor-penetrating peptide enhances the efficacy of cancer drugs. Science. 2010;328:1031-1035. 
3. Colditz GA, Sellers TA, Trapido E. Epidemiology - identifying the causes and preventability of cancer? Nat Rev Cancer. 2006;6:75-83.

4. Shiekh FA. Blood-brain barrier: a real obstacle for therapeutics. Int J Nanomedicine. 2012;7:4065-4066.

5. Horton JK, Wilson SH. Predicting enhanced cell killing through PARP inhibition. Mol Cancer Res. November 27, 2012. [Epub ahead of print.]

6. Horton JK, Gleason JF Jr, Klepin HD, Isom S, Fried DB, Geiger AM. Age-related disparities in the use of radiotherapy for treatment of localized soft tissue sarcoma. Cancer. 2011;117:4033-4040.

7. Godat LN, Horton JK, Shen P, Stewart JH, Wentworth S, Levine EA. Recurrence after mastectomy for ductal carcinoma in situ. Am Surg. 2009;75:592-595.

8. Service RF. Materials and biology. Nanotechnology takes aim at cancer. Science. 2005;310:1132-1134.

9. Reed JC. Cancer. Priming cancer cells for death. Science. 2011;334: 1075-1076.

10. Ryan RJ, Bernstein BE. Molecular biology. Genetic events that shape the cancer epigenome. Science. 2012;336:1513-1514.

11. Cao Y, DePinho RA, Ernst M, Vousden K. Cancer research: past, present and future. Nat Rev Cancer. 2011;11:749-754.

12. Gewin V. Big opportunities in a small world. Nature. 2009;460: 540-541.

13. Hassan MH. Nanotechnology. Small things and big changes in the developing world. Science. 2005;309:65-66.

14. Sukhanova A, Even-Desrumeaux K, Kisserli A, et al. Oriented conjugates of single-domain antibodies and quantum dots: toward a new generation of ultrasmall diagnostic nanoprobes. Nanomedicine. 2012;8:516-525.
15. Jain RK, Stylianopoulos T. Delivering nanomedicine to solid tumors. Nat Rev Clin Oncol. 2010;7:653-664.

16. Prabhu $\mathrm{P}$, Patravale V. The upcoming field of theranostic nanomedicine: an overview. J Biomed Nanotechnol. 2012;8:859-882.

17. Umar A, Dunn BK, Greenwald P. Future directions in cancer prevention. Nat Rev Cancer. 2012;12:835-848.

18. Cheng Z, Al Zaki A, Hui JZ, Muzykantov VR, Tsourkas A. Multifunctional nanoparticles: cost versus benefit of adding targeting and imaging capabilities. Science. 2012;338:903-910.

19. Kozako T, Arima N, Yoshimitsu M, Honda SI, Soeda S. Liposomes and nanotechnology in drug development: focus on oncotargets. Int J Nanomedicine. 2012;7:4943-4951.

20. Meyer UA. Personalized medicine: a personal view. Clin Pharmacol Ther. 2012;91:373-375.

21. Chin L, Andersen JN, Futreal PA. Cancer genomics: from discovery science to personalized medicine. Nat Med. 2011;17:297-303.

22. Shute N. Personalized medicine. Sci Am. 2012;306:44.

23. Sanhai WR, Sakamoto JH, Canady R, Ferrari M. Seven challenges for nanomedicine. Nat Nanotechnol. 2008;3:242-244.

24. Gershon D. Toxicogenomics gains impetus. Nature. 2002;415:4-5.

25. William WN Jr, Heymach JV, Kim ES, Lippman SM. Molecular targets for cancer chemoprevention. Nat Rev Drug Discov. 2009;8:213-225.
International Journal of Nanomedicine

\section{Publish your work in this journal}

The International Journal of Nanomedicine is an international, peerreviewed journal focusing on the application of nanotechnology in diagnostics, therapeutics, and drug delivery systems throughout the biomedical field. This journal is indexed on PubMed Central, MedLine, CAS, SciSearch ${ }^{\circledR}$, Current Contents ${ }^{\circledR} /$ Clinical Medicine,

\section{Dovepress}

Journal Citation Reports/Science Edition, EMBase, Scopus and the Elsevier Bibliographic databases. The manuscript management system is completely online and includes a very quick and fair peer-review system, which is all easy to use. Visit http://www.dovepress.com/ testimonials.php to read real quotes from published authors. 